\title{
KAJIAN NARATIF ANTROPOLOGI DAN PENDIDIKAN
}

\author{
LAURENSIUS ARLIMAN S \\ Mahasiswa Pascasarjana Universitas Negeri Padang \\ laurensiusarliman@gmail.com
}

\begin{abstract}
Anthropology of science education that was born in the mid-20th century. The question that arose at that time was the extent to which education could change society, the frame of mind at that time how to develop development in developing countries and indeed at that time developed countries like Europe were thinking of doing it. changes in society develop through its programs, so that educational anthropology tries to find patterns of community learning culture that can create a change.
\end{abstract}

Keywords: Study, Narrative, Anthropology, Education.

Abstrak: Antropologi pendidikan ilmu yang lahir pada pertengahan abad 20. Pertanyaan yang muncul saat itu adalah sejauhmana pendidikan dapat merubah masyarakat, kerangka berpikirnya waktu itu bagaimana mengembangkan pembangunan di negara-negara berkembang dan memang pada saat itu negara-maju seperti eropah sedang berpikir untuk melakukan perubahan-perubahan didalam masyarakat berkembang melalui program- programnnya, sehingga antropologi pendidikan berusaha menemukan pola budaya belajar masyarakat yang dapat menciptakan suatu perubahan.

Kata Kunci: Kajian, Naratif, Antropologi, Pendidikan.

\section{A. Pendahuluan}

Manusia adalah makhluk hidup yang diberikan berbagai potensi oleh Tuhan, setidaknya manusia diberikan panca indera dalam hidupnya. Namun tentu saja potensi yang dimilikinya harus digunakan semaksimal mungkin sebagai bekal dalam menjalani hidupnya. Untuk memaksimalkan semua potensi yang dimiliki oleh kita sebagai manusia, tentunya harus ada sesuatu yang mengarahkan dan membimbingnya, supaya berjalan dan terarah sesuai dengan apa yang diharapkan. Mengingat begitu besar dan berharganya potensi yang dimiliki manusia, maka manusia harus dibekali dengan pendidikan yang cukup sejak dini. Dilain pihak manusia juga memiliki kemampuan dan diberikan akal pikiran yang berbeda dengan makhluk yang lain. Sedangkan pendidikan itu adalah usaha yang disengaja dan terencana untuk membantu perkembangan potensi dan kemampuan manusia agar bermanfaat bagi kepentingan hidupnya (Sukardjo dan Ukim Komarudin, 2009).

Pendidikan dapat diartikan sebagai suatu proses pembelajaran, pemberian pengetahuan, keterampilan dan sikap melalui pikiran, karakter serta kapasitas fisik dengan menggunakan pranata-pranata agar tujuan yang ingin dicapai dapat dipenuhi. Pendidikan dapat diperoleh melalui lembaga formal dan informal. Penyampaian kebudayaan melalui lembaga informal dilakukan melalui enkulturasi semenjak kecil di dalam lingkungan keluarga. Dalam masyarakat yang sangat kompleks, terspesialisasi dan berubah cepat, pendidikan memiliki fungsi yang sangat besar dalam memahami kebudayaan sebagai satu keseluruhan. Kebudayaan tidak dibawa manusia sejak kelahirannya. Secara faktual, dan sebagaimana tersurat dalam definisi yang dikemukakan Koentjaraningrat, kebudayaan dapat menjadi milik diri manusia sehingga menjadi karakteristiknya yang esensial dibanding dengan hewan hanyalah melalui EISSN 2657-0289 Lembaga Penelitian dan Penerbitan Hasil Penelitian Ensiklopedia $\quad 25$ 
belajar. Di pihak lain, bahwa kebudayaan sebagai keseluruhan sedikit banyak merupakan himpunan dari pola-pola budaya yang diperlukan dalam rangka mempertahankan eksistensi suatu masyarakat (Wahyudin Dinn, 2008).

Kegiatan proses pembelajaran dalam pendidikan tidak mungkin dan tidak dapat dilepaskan dari latar belakang yang melingkupinya, terdapat berbagai hal dalam landasan-landasan pendidikan yang harus dipahami sebagai seorang tenaga pendidik yang profesional. Salah satu landasan yang penting dalam pendidikan adalah landasan antropologi, akan tetapi landasan ini jarang sekali dibahas dalam dunia pendidikan. Kebanyakan buku-buku pendidikan pada umumnya hanya sering mengkaji landasan psikologi, landasan sosiologi, landasan ekonomi, landasan yuridis, dan landasan filsafat. Namun demikian, antropologi secara dominan memberikan peranan dalam pembangunan bangsa Indonesia (Swasono, 2006).

Antropologi pendidikan dihasilkan melalui khusus dan percobaan yang terpisah dengan kajian yang sistrmatis mengenai praktek pendidikan dalam prespektif budaya, sehingga antropologi menyimpulkan bahwa sekolah merupakan sebuah benda budaya yang menjadi skema nilai-nilai dalam membimbing masyarakat (S.W. Septiarti, 2017). Namun ada kalanya sejumlah metode mengajar kurang efektif dari media pendidikan sehingga sangat berlawanan dengan data yang didapat di lapanga, oleh para antropolog. Tugas para pendidik bukan hanya mengekploitasi nilai kebudayaan namun menatanya dan menghubungkannya dengan pemikiran dan praktek pendidikan sebagai satu keseluruhan.

\section{B. Metodologi Penelitian}

Penelitian naratif dapat dianggap sebagai metode penelitian itu sendiri tetapi juga dapat dianggap fenomena yang diteliti. Metode naratif dapat dianggap sebagai "ukuran dunia nyata" yang sesuai ketika "masalah kehidupan nyata" diselidiki. Dalam pendekatan linier dasar, mereka mencakup studi tentang pengalaman seorang individu yang merangkul kisah-kisah kehidupan dan mengeksplorasi signifikansi yang dipelajari dari pengalaman individu tersebut. Namun, dalam kebanyakan kasus seseorang akan menciptakan kumpulan narasi yang masing-masing bertumpu pada yang lain. Penelitian naratif ditetapkan oleh validasi audiens. Ini adalah bagian yang berguna dari penyelidikan ilmu sosial, tetapi mungkin tidak selalu berdiri sendiri untuk bukti dan dukungan dalam penarikan kesimpulan laporan. Timbul pertanyaan tentang keakuratan cerita yang dilihat secara objektif meskipun harus dilihat dalam konteks sosial budaya. Narasi memberikan pandangan individu untuk diakses berdasarkan kemampuannya. Validasi semacam itu dimungkinkan dengan menguatkan dari wacana lain yang mulai naratif. Penekanannya adalah pada pengalaman bertingkat.

\section{Hasil dan Pembahasan}

\section{Definisi Antropologi}

Antropologi berasal dari kata Yunani antropos yang artinya manusia dan logos yang berarti ilmu sehingga antropologi dapat didefinisikan disiplin yang mempelajari manusia beradasarkan rasa ingin tahu yang tiada henti-hentinya (T. Ihromi, 2006:1). Sedangkan Koentjaraningrat mendefinisikan antropologi sebagai ilmu yang mempelajari manusia pada umumnya dengan mempelajari aneka warna, bentuk fisik masyarakat, serta kebudayaan yang dihasilkan. Sebagaimana ilmu-ilmu sosial lainnya misalnya sosiologi, psikologi, antropologi juga mempelajari perilaku manusia khususnya pada aspek budayanya, cara hidup atau perilaku manusia yang berpola. 
Antropologi merupakan salah satu cabang ilmu sosial yang mempelajari budayabudaya masyarakat. Antropologi mempelajari manusia sebagai makhluk biologis sekaligus makhluk sosial. Antropologi dan sosiologi sekilas hampir mirip namun berbeda, antropologi memusatkan pada penduduk yang merupakan masyarakat tunggal, sedangkan sosiologi menitikberatkan pada masyarakat dan kehidupan sosialnya. Prinsip kajian yang berbeda tersebut kemudian memenga- ruhi kajian secara metodologisnya. Akan tetapi, dalam perkembangannya kedua ilmu yang satu rumpun memiliki kontribusiya masing-masing dalam mempelajari fenomena sosial (Tilaar, H.A.R, 2002).

Sebagai cabang ilmu sosial, antropologi memiliki sifat empirik deskriptif, artinya bahwa ilmu tersebut berbicara sebagaimana adanya. Antropologi menggambarkan fenomena sosial dan perilaku manusia sebagai makhluk individu dan sosial dari etnisetnis tertentu yang bisa dilihat (diobserve), diraba atau yang kasat mata. Antropologi merupakan salah satu cabang ilmu sosial yang mempelajari budaya budaya masyarakat. Antropologi mempelajari manusia sebagai makhluk biologis sekaligus makhluk sosial. Antropologi dan sosiologi sekilas hampir mirip namun berbeda antropologi memusatkan pada penduduk yang merupakan masyarakat tunggal, sedangkan sosiologi menitikberatkan pada masyarakat dan kehidupan sosialnya. Antropologi lahir atau berawal dari ketertarikan orang-orang Eropa pada ciri-ciri fisik, adat istiadat, dan budaya etnis-etnis lain yang berbeda dari masyarakat yang dikenal di Eropa. Antropologi lebih memusatkan pada penduduk yang merupakan masyarakat tunggal, tunggal dalam arti kesatuan masyarakat yang tinggal di daerah yang sama, memiliki ciri fisik dan bahasa yang digunakan serupa, serta cara hidup yang sama (S.W. Septiarti, 2017). Masyarakat sederhana, primitif dengan kehidupan tradisionalnya sering dikenal sebagai area pengamatan para antropolog. Berikut pengertian Antropologi menurut para ahli.

\section{Definisi Pendidikan}

Pendidikan adalah fenomena yang fundamental atau asasi dalam kehidupan manusia. Kita dapat mengatakan, bahwa di mana ada kehidupan manusia, bagaimanapun juga di situ pasti ada pendidikan. Pendidikan sebagai gejala yang universal, merupakan suatu keharusan bagi manusia, karena disamping pendidikan sebagai gejala sekaligus juga sebagai upaya memanusiakan manusia itu sendiri. Dengan penrkembangan kebudayaan manusia, timbullah tuntutan akan adanya pendidikan yang terselenggara lebih baik, lebih teratur dan didasarkan atas pemikiran yang matang. Manusia ingin lebih mempertanggungjawabkan caranya dia mendidik generasi penerusnya agar lebih berhasil dalam melaksanakan hidupnya, dalam pertemuan dan pergaulannya dengan sesama dan dunia serta dalam hubungannya dengan Tuhan. Di sinilah muncul keharusan pemikiran teoritis tentang pendidikan.

Suatu kawasan studi dapat tampil atau menampilkan diri sebagai suatu disiplin ilmu, bila dipenuhi setidak-tidaknya tiga syarat, yaitu (1) memiliki objek studi (objek material dan objek formal), (2) memiliki sistematika dan (3) memiliki metode (Lieung, 2020). Yang menjadi objek material ilmu pendidikan adalah perilaku manusia. Apabila kita pelajari perilaku manusia sebagai makhluk yang hidup di dalam masyarakat maka perilaku itu disamping dapat dilihat, segi ilmu pendidikan juga dapat dilihat dan segisegi yang lain seperti psikologis, sosiologis, antropologis. Yang membedakan suatu ilmu dengan ilmu lainnya adalah objeknya. Apabila kebetulan objek materialnya sama, maka yang membedakan satu ilmu dengan ilmu lainnya adalah objek formalnya. Objek 
formal adalah objek material yang disoroti oleh suatu ilmu, atau sudut pandang tertentu yang menentukan macam ilmu.

Berikut ini akan dibahas tentang syarat kedua disiplin ilmu, yaitu memiliki sistematika. Secara teoritik sistematika ilmu pendidikan dapat dibedakan menjadi tiga segi tinjauan, yaitu (S.W. Septiarti, 2017): (1) melihat pendidikan sebagai gejala manusiawi, (2) dengan melihat pendidikan sebagai upaya sadar dan (3) dengan melihat pendidikan sebagai gejala manusiawi, sekaligus upaya sadar dengan mengantisipasi perkembangan sosio-budaya di masa depan.

\section{Manfaat Antropologi Pendidikan dan Masyarakat di Indonesia}

Setiap manusia memiliki perbedaan, oleh karena itu seorang pendidik harus sedikit banyak memahami latar siswa yakni keluarga, budaya, lingkungan siswa. Oleh karena itu, antropologi dibutuhkan sebagai landasan dalam pendidikan. Antropologi dalam pendidikan memiliki beberapa manfaat diantaranya (Rohmad, Z. 2018): 1) Dapat mengetahui pola perilaku manusia dalam kehidupan bermasyarakat secara Universal maupun pola perilaku manusia pada tiap-tiap masyarakat (suku bangsa); 2) Dapat mengetahui kedudukan serta peran yang harus kita lakukan sesuai dengan harapan warga masyarakat dari kedudukan yang kita sandang; 3) Dengan mempelajari antropologi akan memperluas wawasan kita terhadap tata pergaulan umat manusia diseluruh dunia khususnya Indonesia yang mempunyai kekhususan-kekhususan yang sesuai dengan karakteristik daerahnya sehingga menimbulkan toleransi yang tinggi; dan 4) Dapat mengetahui berbagai macam problema dalam masyarakat serta memiliki kepekaan terhadap kondisi-kondisi dalam masyarakat baik yang menyenangkan serta mampu mengambil inisiatif terhadap pemecahan permasalahan yang muncul dalam lingkungan masyarakatnya.

Perbedaan geografis melahirkan pula perbedaan kebudayaan, baik dalam wujud ide-ide, pola, tingkah laku maupun kebudayaan. Di daerah subur seperti di Indonesia, dimana manusia tidak perlu berjuang keras untuk mempertahankan hidupnya, dimana sumber-sumber alam relatif mudah diambil, membuat manusia juga bermurah hati terhadap sesamanya, sehingga bila ada seorang warga masyarakat yang mengalami kekurangan, orang launn dengan mudahnya membantu orang yang menderita tersebut. Karena itu terutama di pedesaan, dimana kebutuhan hidup dari alam sekitar relatif lebih mudah didapatkan, perasaan gotong-royong antar warga masyarakat sangat tinggi. Sebaliknya di daerah perkotaan dimana manusia harus berusaha lebih keras untuk mempertahankan hidupnya, maka perasaan gotong-royong itu makin menipis, dan perasaan individualitasnya lebih tinggi (Rohmad, Z. 2018):. Hal-hal tersebut diatas juga mempengaruhi sistem nilai budaya yang dianut oleh warga masyarakat, yang dengan sendirinya akan berpengaruh terhadap proses pendidikan yang berlangsung di masyarakat yang bersangkutan, karena proses pendidikan tersebut tidak dapat dilepaskan dari lingkungan geografis dan sosiokultural masyarakat.

Studi antropologi selain untuk kepentingan pengembangan ilmu itu sendiri, di negara-negara yang telah membangun sangat diperlukan bagi pembuatan-pembuatan kebijakan dalam rangka pembangunan dan pengembangan masyarakat. Landasan antropologis pendidikan adalah asumsi-asumsi yang bersumber dari kaidah-kaidah antropologi yang dijadikan titik tolak dalam pendidikan. Contoh: perbedaan kebudayaan masyarakat di berbagai daerah (misalnya: sistem mata pencaharian, bahasa, kesenian). Mengimplikasikannya perlu diberlakukan kurikulum muatan lokal. Dari paparan diatas pendidikan perlu dilandasi antropologi karena melalui antropologi 
bisa membuka diri tentang keanekaragaman budaya yang dimiliki oleh Indonesia dan menghargai kebudayaan orang lain.

Hal-hal yang harus diperhatikan dalam implikasi landasan antropologi, adalah sebagai berikut (Rachmat Satria, 2020): 1) Identifikasi kebutuhan belajar masyarakat Identifikasi kebutuhan masayarakat ini bersumber dari informasi masyarakat sekitar. Masyarakat tersebut terdiri dari tokoh masyarakat, baik secara formal maupun informal, tokoh agama, dan perwakilan masyarakat kelas bawah. Hal ini bertujuan untuk memperoleh informasi dan data yang dijadikan bahan pengembangan kurikulum; 2) Keterlibatan partisipasi masyarakat Setelah mengidentifikasi kebutuhan belajar, maka masyarakat ikut serta dalam merancang kurikulum, menyediakan sarana dan prasarana, menentukan nara sumber sebagai fasilitator, dan ikut menilai hasil belajar; 3) Pemberian pendidikan kecakapan hidup Pendidikan kecakapan hidup merupakan pendidikan dalam bentuk pemberian keterampilan dan kemampuan dasar pendukung fungsional, membaca, menulis, berhitung, memecahkan masalah, mengelola sumber daya, bekerja dalam kelompok, dan menggunakan teknologi.

\section{Penutup}

Antropologi adalah ilmu yang mengkaji manusia dan kebudayaannya, antropologi terdiri dari atas antropologi fisik dan antropologi budaya. Antropologi fisik mempelajari: 1) Hubungan antara antropologi dan pendidikan; 2) Spesialisasi antropologi, antropologi pendidikan; dan 3) Peran antropologi pendidikan evolusi fisik manusia dan proses adaptasinya terhadap lingkungan yang berbeda-beda. Antropologi budaya memfokuskan pada kajian kebudayaan dulu sampai sekarang, kebudayaan dari masyarakat yang sederhana sampai masyarakat yang sudah maju, dimana kebudayaan itu dikaji secara spesifik dan unik, dalam artian juga antropologi yang menyadari keragaman budaya umat manusia. Pendidikan adalah proses pembelajaran pengetahuan , ketrampilan dan nilai kepada orang lain dengan mengunakan pranata pranata dan institusi yang ada didalam masyarakat yang tujuan untuk menciptakan suatu kecerdasan intelektual, kecerdasan sosial emosi , kecerdasan spritual serta kecerdasan budaya. Pendidikan diperoleh melalui lembaga formal dan informal. Dalam proses transmisi kebudayaan (pewarisan kebudayaan) melalui lembaga informal erjadi proses sosialisasi dan enkulturasi semenjak jkecil dalam lingkungan keluarga. Melalui proses pendidikan ini memiliki fungsi yang strategis dalam memahami kebudayaan sebagai satu keselururan sistem yang ada di dalam masyarakat. Adanya perkembangan zaman yang semakin cepat, membutuhan waktu yang banyak untuk dapat memahamai kebudayaan masyarakat yang dimiliki oleh kelompok-kelompok sosial.untuk itu diperlukan metode-metode yang baru untuk mempelajari kebudayan ini dan diperlukan kerja sama antara pendidik dan antropolog untuk menganalisis dan mencari potensipotensi kebudayaan yang dapat menyesuaikan diri dengan tuntutan perkembangan zaman yang ada dan memikirkan kesiapan sosial budaya masyarakat dalam menghadapi perubahan sosial budaya.

\section{Daftar Pustaka}

Ihromi, T.O. (2006). Pokok-pokok Antropologi Budaya. Yayasan Obor Indonesia, Jakarta.

Karlina Wong Lieung, (2020), Penggunaan Metode Pembelajaran Peta Konsep Untuk Meningkatkan Hasil Belasar IPS dan Karakter Nasionalis Siswa Kelas IV SD Inpres Semangga 1 Merauke, Jurnal Ilmu Pendidikan, Keguruan, \& Pembelajaran, Vol.4, No.1. 
Rachmat Satria, dkk (2020) Landasan Antropologi Pendidikan dan Implementasinya Dalam Pembangunan Indonesia, Indonesian Journal of Social Science Education (IJSSE), Volume 2, Nomor 1.

Rohmad, Z. (2018). Problematika Pendidik Sosiologi Antropologi Di Masyarakat Multikultural. Habitus: Pendidikan, Jurnal Dan Sosiologi Antropologi, Volume 2, Nomor 1.

Sukardjo, M. dan Komarudin, Ukim. (2009). Landasan Pendidikan Konsep dan Aplikasinya. RajaGrafindo Persada. Jakarta.

S.W. Septiarti, dkk., (2017), Sosiologi dan Antropologi Pendidikan, UNY Press, Yogyakarta.

Tilaar, H.A.R. (2002). Pendidikan, Kebudayaan, dan Masyarakat Madani Indonesia. Penerbit PT Remaja Rosdakarya, Bandung.

Wahyudin, Dinn. (2008). Pengantar Pendidikan. Universitas Terbuka, Jakarta. 